\title{
Translation of Reflective Thinking Questionnaire: A Structural Equation Model
}

\author{
Laras Firdaus ${ }^{1}$, Masiah$^{1 *}$, Ibrohim², Sri Rahayu Lestari², Ika Nurani Dewi' ${ }^{1}$, Alwan Mahsul ${ }^{3}$, Agus \\ Muliadi $^{1}$ \\ ${ }^{1}$ Universitas Pendidikan Mandalika, Mataram, Indonesia \\ ${ }^{2}$ Universitas Negeri Malang, Malang, Indonesia \\ ${ }^{3}$ Universitas Islam Negeri Mataram, Mataram, Indonesia
}

\section{DOI: $\underline{10.29303 / \text { jppipa.v7iSpecialIssue.1036 }}$}

\section{Article Info}

Received: October 13 th, 2021

Revised: December 12th, 2021

Accepted: December 16 ${ }^{\text {th }}, 2021$

\begin{abstract}
The purpose of this study is to translate, validate the reflective thinking questionnaire, and to explain the reflective thinking profile of UIN Mataram biology prospective teachers. A total 243 of UIN Mataram biology prospective teacher as voluntary respondents. The data analysis process was carried out using the JASP for windows analysis package. Structural equation model testing based on $P$-value, CFI, and RMSEA. The results of the confirmatory factor analysis, from 16 items were analyzed, only 11 items supported a fit model, with $P$-value $=0.225, C F I=0.986$, and RMSEA $=0.026$. The 11 items reflect four categories of RT (understanding, reflection, habitual action, and critical reflection), show high internal consistency, and show good construct validity. The translation of the RT questionnaire was declared valid and could be used to measure RT.
\end{abstract}

Keywords: Reflective thinking; structural equation model; confirmatory factor analysis

Citation: Firdaus, L., Masiah, M., Ibrohim, I., Lestari, S. R., Dewi, I. N., Mahsul, A., \& Muliadi, A. (2021). Translation of Reflective Thinking Questionnaire: A Structural Equation Model. Jurnal Penelitian Pendidikan IPA, 7(SpecialIssue), 305-311. https:// doi.org/10.29303/ippipa.v7iSpecialIssue.1036

\section{Introduction}

Science and technology continue to develop, making the world more modern and complex. In such conditions, education especially teachers, has a moral and academic responsibility to provide the best education for students at every level, including in higher education (Sarigoz, 2012). Reflective thinking (RT) that must be developed in education in the modern era with all its complexity (Buzdar \& Ali, 2013; Griffin, 2003; Griffith \& Frieden, 2000; Mirzaei et al., 2014b). So many educational studies seek to improve and developing RT (Tutticci, et al., 2016), because RT plays an important role in everyday life (Afshar \& Farahani, 2015). The process of reflection can relate to previous knowledge to problems that are being faced by students, this process will really help students to obtain maximum learning outcomes (Bassachs, et al., 2020), or in other words, RT brings students to the nature of the learning process, bringing them to his main goal of participating in learning, and being part of an active role in the learning process (Demir, 2015), related to critical thinking skills and creative thinking (Akpur, 2020; Funny et al., 2019; Jansen \& Spitzer, 2009), and metacognitive abilities (Lucas, et al., 2017; Shavit \& Moshe, 2019).

The term reflection is also called RT as practiced by practitioners in the practice of reflection, and has been widely studied among in-service teachers in the context of teaching and learning (Phan, 2007). Dewey calls RT as thinking organization or umbrella thinking skills (Semerci, 2007), because RT affects the various thinking skills, such as critical thinking and creative thinking (Akpur, 2020), also related to the problem

\footnotetext{
*Email: masiah@ikipmataram.ac.id
} 
solving process (Buzdar \& Ali, 2013; Gürbüz, 2020; Ocak \& Eğmir, 2016). So that it is difficult to distinguish between RT and problem solving (Sivaci, 2017). Furthermore, Gusrol added that the term RT is more popularly known as modes of thinking, such as metacognitive, critical thinking, analytical thinking, and creative thinking (Mirzaei et al., 2014b), RT can be understood as a very complex model of thinking, covering various types of thinking, such as critical thinking, metacognitive, problem solving, and creative thinking (Deringöl, 2019; Semerci, 2007).

According to Rodgers, the function of RT is to meaning formation and make connections to each experience continuously (Choy, et al., 2017), to develop thinking and increase one's motivation to solve the problems (Can, 2015). According to Sparks-Langer and Colton, RT consists of several components, including narrative inquiry, cognitive components, and critical thinking (Choy et al., 2019), while according to Kember, et al. (2000) RT consists of several components, namely understanding, habitual action, reflection, and critical reflection, and the components or categories of RT by Kember are more widely used by researchers in examining the relationship between RT and various skills or thinking processes (Ghanizadeh \& Jahedizadeh, 2017).

According to Zeichner and Liston's that teachers (instructors) should be reflective thinkers who can make innovations in the learning process (Marzban \& Ashraafi, 2016). Likewise, prospective teacher students must become reflective thinkers, with reflective thinking it will be very impactful when he becomes a teacher (Demir, 2015). The learning process should emphasize or develop RT on prospective teachers, during the learning process, the prospective teacher will acquire the knowledge, abilities, competencies, and various skills needed for effective and efficient teaching and learning (Mirzaei, et al., 2014b). Empirical evidence shows that reflection is beneficial in teaching and learning, as it allows students and educators to think critically about their own learning and professional development (Phan, 2007). The teachers who think reflectively have approaches or methods that are more accurate in understanding situations critically when dealing with students and analyzing the situations they face (Poyraz \& Usta, 2003).

The RT questionnaire developed by Kember has been used and studied by several researchers such as Ghanizadeh and Jahedizadeh (2017) adopting and validating a reflective thinking questionnaire, with students majoring in English as the sample or respondents. Sabekti, et al., (2020) adapting and validating a RT questionnaire for chemistry prospective teachers. Furthermore, if we pay attention to the validity conditions of the reflective thinking questionnaire for biology prospective teachers has not been done. In addition, a study on RT at Universitas Islam Negeri Mataram (UIN Mataram), especially the validation of the RT questionnaire has never been carried out, and other aspects, to obtain stability about the validity of the RT questionnaire, so this research is also important to do.

In addition, the research related to reflective thinking does not only focus on measuring validity and reliability but also on the profile of reflective thinking. For this (reflective thinking profile) it depends on the theory used. Some use Van Manen's theory, dividing the profile of reflective thinking into contextual level, dialectical level, and technical level (Mirzaei, et al., 2014a), because this research uses the category (component) of reflective thinking developed by Kember, et al. (2000), namely habitual action, understanding, reflection, and critical reflection. So, the profile of reflective thinking in this study refers to the category (component) of reflective thinking. The research objectives are, first; to translate and validate the RT questionnaire developed by Kember, et al. (2000). Second; to explains the RT profile of UIN Mataram biology prospective teachers.

\section{Method}

This research is survey research. A total 243 UIN Mataram biology prospective teachers as voluntary respondents, then the RT questionnaire was adopted from Kember, et al. (2000), consisting of four categories (understanding, habitual action, reflection, and critical reflection), each category composed of 4 items. A 4choice Likert scale was used to obtain respondents' agreement ( $1=$ strongly disagree, $2=$ disagree, $3=$ agree, and $4=$ strongly agree). Furthermore, the data were analyzed using the JASP for the windows analysis package. To test the model to determine whether the proposed model is fit or not based on the values $(P \geq$ 0.05, CFI> 0.90, and RMSEA< 0.08) (Kim et al., 2016; Stacciarini \& Pace, 2017).

\section{Result and Discussion}

Based on the results of the analysis, Table 1. shows the results of the descriptive analysis, including the average of each item, and standard deviation. Table 2. also shows the results of the descriptive analysis of each category of reflective thinking, it is obtained that habitual action has the lowest average. 
Table 1. The results of the descriptive analysis of each item in each category of RT

\begin{tabular}{lllll}
\hline & Valid & Missing & Mean & Std. Deviation \\
\hline HbA-1 & 243 & 0 & 2.037 & 1.038 \\
HbA-2 & 243 & 0 & 1.975 & 1.040 \\
HbA-3 & 243 & 0 & 2.235 & 1.012 \\
HbA-4 & 243 & 0 & 2.790 & 0.976 \\
Und-5 & 243 & 0 & 3.461 & 0.699 \\
Und-6 & 243 & 0 & 3.815 & 0.430 \\
Und-7 & 243 & 0 & 3.852 & 0.389 \\
Und-8 & 243 & 0 & 3.226 & 0.762 \\
Ref-9 & 243 & 0 & 3.576 & 0.594 \\
Rfl-10 & 243 & 0 & 3.551 & 0.603 \\
Rfl-11 & 243 & 0 & 3.551 & 0.656 \\
Rfl-12 & 243 & 0 & 3.683 & 0.540 \\
CrR-13 & 243 & 0 & 3.177 & 0.861 \\
CrR-14 & 243 & 0 & 2.860 & 1.007 \\
CrR-15 & 243 & 0 & 3.000 & 0.886 \\
CrR-16 & 243 & 0 & 3.128 & 0.879 \\
\hline
\end{tabular}

Note: $\mathrm{HbA}=$ habitual action; Und= understanding; Rfl= reflection; and $\mathrm{CrR}=$ critical reflection

Table 2. The results of the descriptive analysis of each category of RT

\begin{tabular}{lllll}
\hline & Valid & Missing & Mean & $\begin{array}{l}\text { Std. } \\
\text { Deviation }\end{array}$ \\
\hline HbA & 243 & 0 & 6.247 & 2.317 \\
Und & 243 & 0 & 14.354 & 1.574 \\
Rfl & 243 & 0 & 14.362 & 1.751 \\
CrR & 243 & 0 & 12.165 & 2.656 \\
\hline
\end{tabular}

The validation process is carried out using confirmatory factor analysis (CFA), and of course, this is related to the structural equation model (SEM), or in other words, in psychometric research, SEM is used to test the hypotheses of the theoretical model (Byrne, 2001). Based on the results of the analysis as shown in Figure 1, it is a fit model after being modified from its initial model, because does not match the criteria values for a fit model, after being modified by removing several items from the analysis process, 11 items are obtained which composes a fit model, with $P$-value $=$ 0.225 , RMSEA $=0.026$ (RMSEA < 0.08), CFI $=0.986$ (CFI> $0.90)$, and the loading factor value is greater than 0.5 .

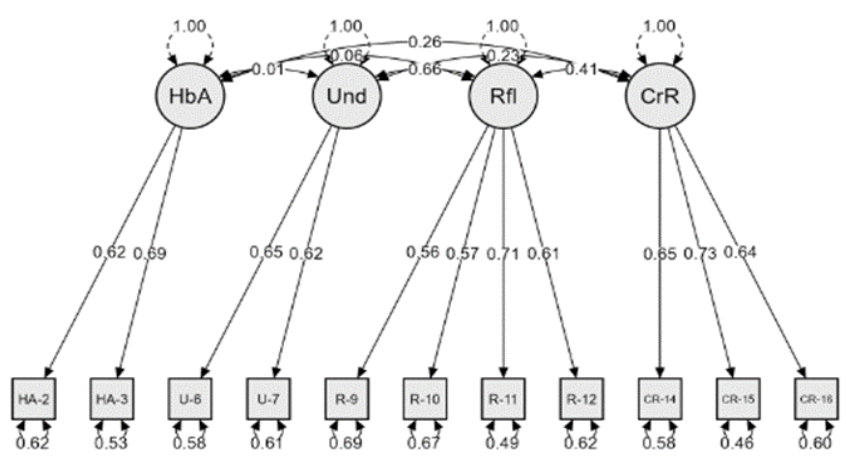

Figure 1. The relationship model of reflective thinking categories
Table 3. AVE, CR coefficient, correlation between constructs with the square root of AVE

\begin{tabular}{lclllll}
\hline Category & AVE & CR & HbA & Und & Rfl & CrR \\
\hline HA & 0.71 & 0.83 & $(0.84)$ & & & \\
Und & 0.55 & 0.78 & 0.05 & $(0.74)$ & & \\
Ref & 0.53 & 0.82 & 0.02 & 0.45 & $(0.73)$ & \\
CrR & 0.63 & 0.84 & 0.18 & 0.21 & 0.29 & $(0.79)$ \\
\hline
\end{tabular}

Descriptively about the RT of UIN Mataram biology prospective teachers can be seen in Table 2. that habitual action has the lowest average. This result is relatively the same with the results shown by Ghanizadeh and Jahedizadeh, (2017), habitual action has the lowest average (10.17) among other categories of reflective thinking. Likewise with the results shown by Sabekti, et al. (2020) the average for habitual action in general is 14.60. Habitual action refers to actions that are carried out spontaneously, or actions without thoughtful processes (Kember, et al., 2000). Furthermore Kember explain that the action without a thoughtful process is an action that a person is used to as a result of the habituation process, or in other words one's experiences in solving a problem which the settlement process continues to be accustomed, and when faced with the same problem, the resolution process is carried out spontaneously. Gelter, (2003) that during the reflection process, relevant thought can be generated, and if done continuously, the result can be spontaneously selecting relevant thoughts. From this statement can be understood that if the activity or thoughtful process is continuously carried out at a later stage it becomes a habit, and when faced with a similar problem, the analysis process can be carried out spontaneously. For Mezirow, learning is understood as a process of changing the initial interpretation into a new interpretation based on experience, or the process of interpreting the activities and subsequently becoming a guide for someone in solving a problem (Calleja, 2014). So that even though the habitual action category has a low average compared to other categories of RT, this indicates that UIN Mataram biology prospective teachers do not habituating on understanding, reflection, and critical reflection.

The understanding category refers to a thoughtful act, or described as a thinking process (Kember, et al., 2000), and this is why UIN Mataram biology prospective teachers' students have the awareness that it requires thinking to understand lecture materials, or in other words to get learning outcomes, each lecture material must be well understood. Then reflection is a conscious process, an active and focused, structured thinking process, this criterion is what distinguishes the process of reflection and day dreaming (Gelter, 2003). Kember, et al. (2000) explains that the process of reflection in the context of 
learning refers to a person's intellectual and affective activities to explore his experiences to gain understanding. From Table 2 above, the reflection category has the highest average, indicating that UIN Mataram biology prospective teachers tend to often evaluate their actions that have been taken, and try to correct the mistakes they have made. According to Gelter; Kember opinions, basically the categories of understanding and reflection are closely related (the correlation value between Und and Ref is $0.45, P<$ $0.001)$, but on the other hand, someone can have a good understanding of a concept without having to go through a process of reflection, vice versa someone who uses the process of reflection certainly has an understanding of a concept.

Furthermore, with regard to the validation process, it seems that there is something lacking if we only talk about validity without including talking about reliability. Mat Nawi, et al. (2020) explains that although the concepts of validity and reliability are different, basically these two concepts are very important in the development of instruments. Validity refers to the extent to which items (questionnaires) measure what they are supposed to measure, while reliability aims to ensure that the measurement process will obtain consistent results. The concept of reliability is related to repetition to ensure whether the measurement results show the same or relatively the same because it is impossible to get exactly the same results in different measurement time and situations. Because the concept of reliability refers to the stability of the measurement results, so in this study it is not actually measuring reliability, but measuring internal consistency. Internal consistency is used to test respondents' feedback on research instruments, whether the response is consistent or not (Mat Nawi et al., 2020), and usually the value of internal consistency is measured or determined based on the value of the aCronbach coefficient (Heale \& Twycross, 2015; Kim et al., 2016; Trizano-Hermosilla \& Alvarado, 2016; Villafañe, et al., 2011). So that internal consistency cannot be used to estimate reliability (Tang et al., 2014).

The measurement of internal consistency in this study uses the $C R$ value because $C R$ is an alternative to the a-Cronbach coefficient (Ghazali \& Nordin, 2019). A measure of internal consistency reliability for latent variables (constructs) with CR> 0.7 (Saeed \& Kassim, 2017), and when actual reliability is estimated using SEM, the resulting estimate is usually referred to CR (Peterson \& Kim, 2013). Based on Table 3. it is known that the CR is above 0.7. So can be stated that the 11 items obtained through the CFA have high internal consistency. This indicates that the respondents gave a consistent response to the 11 items that represent each of their constructs, or in other words, the 11 items can measure what should be measured. The level of internal consistency is influenced by whether or not an item is valid. So that invalid items must be excluded from the analysis process, but what needs to be noted is that internal consistency is necessary, but is not a criterion for the construct validity (Churchill, 1979). So that even though the internal consistency value is high, or even close to perfect, to test the validity of the construct, further tests must be carried out.

According to Bertea, (2011), construct validity includes convergent, discriminant, and nomological validity, because the large amount of evidence that must be collected makes it difficult to analyze (Engellant, et al., 2016), so in this study, the testing of construct validity includes convergent and discriminant validity. As stated above, the validation process of the RT questionnaire was carried out using CFA. The RT category relationship model as shown in Figure 1 , is a fit model based on $P$-values $>0.05$, CFI> 0.90 , and RMSEA< 0.08. In the analysis process, 11 items were obtained that support a fit model, or the 11 items could represent their constructs. In addition, in the analysis process, 5 items were excluded from the analysis process. This indicates, first; the items not represent their construct. Second; the expenditure of these items can be understood, when retesting, both on the same or different samples, the items issued must be revised, perhaps the 5 items issued are caused by poor translational factors, so the respondents misunderstand the meaning of the items.

Convergent validity measures the degree of correlation between items in the same construct, while discriminant validity refers to the extent to which each construct is empirically different from other constructs (Ab Hamid, et al., 2017), or how each construct is correlated with one another (Hair, 2014). According to Ab Hamid, et al. (2017); Kim, et al. (2016); Muhammad, et al. (2017), the good evidence for convergent validity is the loading factor value, average variance extracted (AVE) greater than 0.5 , and composite reliability (CR) is above 0.7, while according to Bertea (2011) the good evidence for discriminant validity is the value of the square root of AVE, which must be higher than the correlation between items, both on the same construct and on different constructs.

Based on the information in Table 3. above, the values contained in brackets are the values square root of AVE, while the values that are not in brackets are correlation values between constructs, this indicates that the 11 items obtained through CFA have convergent validity (loading factor value $>0.5$, AVE> 0.5 , and CR> 0.7). According to Kim et al. (2016) that the low convergent validity indicates there are contribution variance from other constructs besides their construct itself. From the value of CR> 0.7. So can 
be stated that the 11 items have good convergent validity, each construct does not share their variance to other constructs, because each construct only provides variance to the items that compose it, then the 11 items also meet the criteria of discriminant validity, or in other words, each construct shows a significant difference, and each construct measures the items that compose it.

\section{Conclusion}

Based on the results of the analysis and the limitations of the discussion, it is known that the habitual action category has the lowest average compared to other categories of reflective thinking (understanding, reflection, and critical reflection). From the 16 items were analyzed using CFA, 11 items were obtained that support a fit model. The 11 items were declared valid, both from the aspect of convergent and discriminant validity. Through this result, a valid translation of the RT questionnaire is available, and this questionnaire can be used to examine the relationship between RT and thinking skills, such as critical thinking skills, but it is important to note that 5 items were removed from the analysis process in this study to be revised back before the full use of all the items in each category of RT.

\section{Acknowledgments}

Thanks to the Ministry of Education and Culture, Research and Technology for financial support in completing this research through Decree No. 168/E4.1/AK.04.PT/2021.

\section{References}

Ab Hamid, M. R., Sami, W., \& Mohmad Sidek, M. H. (2017). Discriminant validity assessment: Use of Fornell \& Larcker criterion versus HTMT Criterion. Journal of Physics: Conference Series, 890, $012163 . \quad$ https://doi.org/10.1088/17426596/890/1/012163.

Afshar, H. S., \& Farahani, M. (2015). Reflective thinking and reflective teaching among Iranian EFL Teachers: Do Gender and Teaching Experience Make a Difference? Procedia - Social and Behavioral Sciences, 192, 615-620. https://doi.org/10.1016/j.sbspro.2015.06.107.

Akpur, U. (2020). Critical, reflective, creative thinking and their reflections on academic achievement. Thinking Skills and Creativity, 37, 100683. https://doi.org/10.1016/j.tsc.2020.100683.
Bertea, P. (2011). Methods for testing discriminant validity. ManagementEMarketing, IX(2), 8. Retrieved from: https://econpapers.repec.org/article/aiomanma r/v_3aix_3ay_3a2011_3ai_3a2_3ap_3a217224.htm

Buzdar, M. A., \& Ali, A. (2013). Development of reflective thinking through distance teacher education programs at AIOU Pakistan. The International Review of Research in Open and Distributed Learning, 14(3), 43. https://doi.org/10.19173/irrodl.v14i3.1350.

Byrne, B. M. (2001). Structural equation modeling with AMOS, EQS, and LISREL: Comparative approaches to testing for the factorial validity of a measuring instrument. International Journal of Testing, 1(1), 55-86. https://doi.org/10.1207/S15327574IJT0101_4.

Calleja, C. (2014). Jack Mezirow's conceptualisation of adult transformative learning: A review. Journal of Adult and Continuing Education, 20(1), 117-136. https://doi.org/10.7227/JACE.20.1.8.

Can, S. (2015). Pre-service science teachers reflective thinking skills toward problem solving. Educational Research and Reviews, 10(10), 14491457. https://doi.org/10.5897/ERR2015.2228.

Choy, S. C., Lee, M. Y., \& Sedhu, D. S. (2019). Reflective thinking among teachers: Development and preliminary validation of reflective thinking for teachers questionnaire. Alberta Journal of Educational Research, 65(1), 37-50. https://doi.org/10.11575/ajer.v65i1.56416

Choy, S. C., Yim, J. S.-C., \& Tan, P. L. (2017). Reflective thinking among preservice teachers: A Malaysian perspective. Issues in Educational Research, 27(2). Retrieved from: http:/ /103.247.176.188/FullText.aspx?id=200743 $\underline{360}$

Churchill, G. A. (1979). A paradigm for developing better measures of marketing constructs. Journal of Marketing Research, 16(1), 64. https://doi.org/10.2307/3150876.

Demir, D. S. (2015). Evaluation of critical thinking and reflective thinking skills among science teacher candidates. Journal of Education and Practice, 6. Retrieved from: https://eric.ed.gov/?id=EJ1079684

Deringöl, Y. (2019). The relationship between reflective thinking skills and academic achievement in mathematics in fourth-grade primary school students. Journal of Education and Teaching (IOJET), 6(3), 613-622. Retrieved from: https://eric.ed.gov/?id=EJ1246598

Engellant, K. A., Holland, D. D., \& Piper, R. T. (2019). Assessing Convergent and Discriminant Validity 
of the Motivation Construct for the Technology Integration Education (TIE) Model. Journal of Higher Education Theory and Practice, 16(1). Retrieved from https://articlegateway.com/index.php/JHETP/ article/view/1935.

Funny, R. A., Ghofur, M. A., Oktiningrum, W., \& Nuraini, N. L. S. (2019). Reflective thinking skills of engineering students in learning statistics. Journal on Mathematics Education, 10(3), 445-458. https://doi.org/10.22342/jme.10.3.9446.445-458.

Gelter, H. (2003). Why is reflective thinking uncommon. Reflective Practice, 4(3), 337-344. https://doi.org/10.1080/1462394032000112237.

Ghanizadeh, A., \& Jahedizadeh, S. (2017). Validating the Persian version of reflective thinking questionnaire and probing Iranian university students' reflective thinking and academic achievement. International Journal of Instruction, 10(3), 209-226. https://doi.org/10.12973/iji.2017.10314a.

Griffin, M. L. (2003). Using critical incidents to promote and assess reflective thinking in preservice teachers. Reflective Practice, 4(2), 207-220. https://doi.org/10.1080/14623940308274.

Griffith, B. A., \& Frieden, G. (2000). Facilitating reflective thinking in counselor education. Counselor Education and Supervision, 40(2), 82-93. https://doi.org/10.1002/j.15566978.2000.tb01240.x.

Gürbüz, İ. (2020). Pre-service English language teachers' reflective thinking tendencies and their attitudes towards teaching profession. Innovational Research in ELT, 1(1), 1-9. https://doi.org/10.29329/irelt.2020.311.1.

Hair, J.F., Black, W.C., Babin, B.J., \& Anderson, R.E. (2014). Multivariate data analysis. London: Pearsosn.

Jansen, A., \& Spitzer, S. M. (2009). Prospective middle school mathematics teachers' reflective thinking skills: Descriptions of their students' thinking and interpretations of their teaching. Journal of Mathematics Teacher Education, 12(2), 133-151. https://doi.org/10.1007/s10857-009-9099-y.

Kember, D., Leung, D. Y. P., Jones, A., Loke, A. Y., McKay, J., Sinclair, K., Tse, H., Webb, C., Yuet Wong, F. K., Wong, M., \& Yeung, E. (2000). Development of a questionnaire to measure the level of reflective thinking. Assessment $\mathcal{E}$ Evaluation in Higher Education, 25(4), 381-395. https://doi.org/10.1080/713611442.

Kim, H., Ku, B., Kim, J. Y., Park, Y.-J., \& Park, Y.-B. (2016). Confirmatory and exploratory factor analysis for validating the phlegm pattern questionnaire for healthy subjects. Evidence-Based
Complementary and Alternative Medicine, 2016, 1-8. https://doi.org/10.1155/2016/2696019.

Lucas, C., Bosnic-Anticevich, S., Schneider, C. R., Bartimote-Aufflick, K., McEntee, M., \& Smith, L. (2017). Inter-rater reliability of a reflective rubric to assess pharmacy students' reflective thinking. Currents in Pharmacy Teaching and Learning, 9(6), 989-995.

https://doi.org/10.1016/j.cptl.2017.07.025.

Marzban, A., \& Ashraafi, N. (2016). Assessing reflective thinking skills in EFL/ESL instructors based on differences in graduation degree and nationality. Reflective Practice, 17(6), 681-693. https://doi.org/10.1080/14623943.2016.1206879.

Mirzaei, F., Phang, F. A., \& Kashefi, H. (2014a). Assessing and improving reflective thinking of experienced and inexperienced teachers. Procedia - Social and Behavioral Sciences, 141, 633-639. https://doi.org/10.1016/j.sbspro.2014.05.111.

Mirzaei, F., Phang, F. A., \& Kashefi, H. (2014b). Measuring teachers reflective thinking skills. Procedia - Social and Behavioral Sciences, 141, 640647.

https://doi.org/10.1016/j.sbspro.2014.05.112.

Muhammad, N. A., Shamsuddin, K., Mohd Amin, R., Omar, K., \& Thurasamy, R. (2017). Questionnaire development and validity to measure sexual intention among youth in Malaysia. BMC Public Health, 17(1), 157. https://doi.org/10.1186/s12889-016-3949-1.

Ocak, G., \& Eğmir, E. (2016). The relationship between pre-service teachers' critical thinking tendencies and problem-solving skills. Participatory Educational Research, spi16(2), 33-44. https://doi.org/10.17275/per.16.spi.2.4.

Peterson, R. A., \& Kim, Y. (2013). On the relationship between coefficient alpha and composite reliability. Journal of Applied Psychology, 98(1), 194-198. https://doi.org/10.1037/a0030767.

Phan, H. P. (2007). An examination of reflective thinking, learning approaches, and self-efficacy beliefs at the university of the South Pacific: A path analysis approach. Educational Psychology, 27(6), 789-806. https://doi.org/10.1080/01443410701349809.

Poyraz, C., \& Usta, S. (2013). Investigation of preservice teachers' reflective thinking tendencies in terms of various variances. International Journal on New Trends in Education and Their Implications, 4(2). Retrieved from: http://www.ijonte.org/FileUpload/ks63207/Fil e/12.poyraz.pdf

Sabekti, A. W., Khoirunnisa, F., \& Liliasari, L. (2020). Validating the Indonesian version of reflective thinking questionnaire and investigation of the 
relationship between pre-service teachers' reflective thinking and academic achievement. Companion Proceedings of the 7th South East Asia Design Research International Conference (SEADRIC 2019), 138-144. https://doi.org/10.24071/seadr.2019.19.

Sarigoz, O. (2012). Assessment of the high school students' critical thinking skills. Procedia - Social and Behavioral Sciences, 46, 5315-5319. https://doi.org/10.1016/i.sbspro.2012.06.430.

Semerci, Ç. (2007). Developing a reflective thinking tendency scale for teachers and student teachers. Educational Sciences: Theory \& Practice, 7(3), 13691376. Retrieved from: https:/ / eric.ed.gov/?id=EJ796245

Shavit, P., \& Moshe, A. (2019). The contribution of reflective thinking to the professional development of pre-service teachers. Reflective Practice, 20(4), 548-561. https:// doi.org/10.1080/14623943.2019.1642190.

Sivaci, S. Y. (2017). The Relationship between reflective thinking tendencies and social problem-solving abilities of pre-service teachers. Journal of Education and Training Studies, 5(11), 21. https://doi.org/10.11114/jets.v5i11.2273.
Stacciarini, T. S. G., \& Pace, A. E. (2017). Confirmatory factor analysis of the appraisal of self-care agency scale-revised. Revista Latino-Americana de Enfermagem, 25(0). https://doi.org/10.1590/1518-8345.1378.2856.

Tang, W., Cui, Y., \& Babenko, O. (2014). Internal consistency: do we really know what it is and how to assess it. Journal of Psychology and Behavioral Science, 2(2), pp. 205-220. Retrieved from: http://jpbsnet.com/vol-2-no-2-june-2014abstract-13-jpbs

Trizano-Hermosilla, I., \& Alvarado, J. M. (2016). Best Alternatives to Cronbach's Alpha Reliability in Realistic Conditions: Congeneric and Asymmetrical Measurements. Frontiers in Psychology, https://doi.org/10.3389/fpsyg.2016.00769.

Tutticci, N., Lewis, P. A., \& Coyer, F. (2016). Measuring third year undergraduate nursing students' reflective thinking skills and critical reflection self-efficacy following high fidelity simulation: A pilot study. Nurse education in practice, 18, 52-59. https://doi.org/10.1016/j.nepr.2016.03.001 